\title{
The Electrolysis of Brine Water With Mercury Jet Cathode*
}

\author{
Shigeru Mizuno**, Shinobu Toshima***
}

It has been known that the impurity ions co-existing in brine water such as $\mathrm{Mg}, \mathrm{Ca}, \mathrm{Fe}, \mathrm{V}$ and $\mathrm{Cr}$ ion give gift actions on the electrolytic efficiency in mercury chlorine cells. The relation between this action and the flow of mercury cathode was studied in the previous paper ${ }^{(1)}$ and it was found that those impurity ions caused the different types of surface flow during electrolysis, and the radiation of ultrasonics could reduce the gift action. (2) From the above results it was suggested that the electrolysis of impure brine water could be carried out with high current efficiency if the cathode was a streaming jet electrode, in which the mercury was continuously renewed at high speed and the working period as cathode was very short. Therefore, by using this jet electrode the electrolysis of brine water was carried out in several cases by changing the brine concentration, streaming velocity, cathodic current density, salt decomposition ratio and the intensity of ultrasonics which was assumed to increase the current efficiency especially in diluted brine water.

Table 1 Relation between Voltage and Electric Current

\begin{tabular}{c|c|c|c|c}
\hline \hline $\begin{array}{c}\text { Streaming } \\
\text { velocity } \\
(\mathrm{m} / \mathrm{sec})\end{array}$ & $\begin{array}{c}\text { Voltage } \\
(\mathrm{V})\end{array}$ & $\begin{array}{c}\text { Electric current } \\
(\mathrm{A} / 1 \text { jet })\end{array}$ & $\begin{array}{c}\text { Jet length } \\
(\mathrm{mm})\end{array}$ & $\begin{array}{c}\text { Cathodic } \\
\text { current density } \\
\left(\mathrm{A} / \mathrm{dm}^{2}\right)\end{array}$ \\
\hline 0.52 & 5.5 & 0.270 & 5 & 1080 \\
0.52 & 6.0 & 0.315 & 5 & 1260 \\
0.52 & 6.5 & 0.390 & 5 & 1560 \\
0.67 & 5.5 & 0.320 & 7 & 910 \\
0.67 & 6.0 & 0.375 & 7 & 1060 \\
0.67 & 6.5 & 0.515 & 7 & 1460 \\
1.08 & 5.5 & 0.375 & 10 & 750 \\
1.08 & 6.0 & 0.455 & 10 & 910 \\
\hline
\end{tabular}

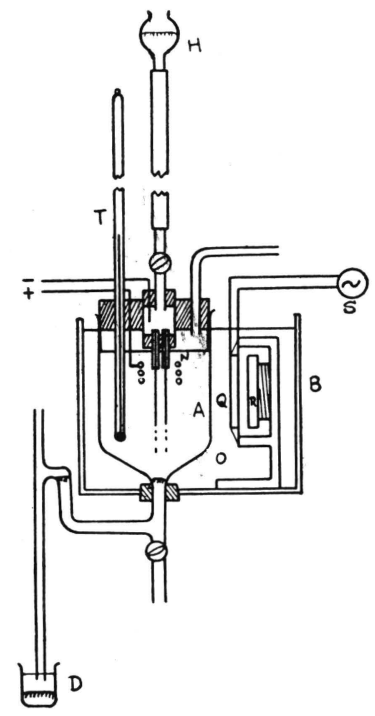
A. Glass electrolytic cell (100 cc)
B. Iron ultrasonics cell
D. Amalgam receiver
H. Mercury reservoir
N. Mercury nozzle
O. Insulating oil
Q. Quartz plate
R. Reflector
S. High frequency oscillator
T. Thermometer

Fig. 1 Experimental apparatus.

* Sudies on the Electrode Surface Phenomena (Part 4).

** Tokyo Institute of Technology, The Reseasch Institute of Resources Utilization.

*** Tokyo Iostitute of Technology.

The original written in Japanese can be seen in J. Electrochem. Soc. Japan ,27, 391 (1959). 
The experimental apparatus is shown in Fig. 1, in which $\mathrm{N}$ denotes capillary nozzle made of glass $82 \mathrm{~mm} \times 0.16 \mathrm{~mm} \phi, \mathrm{A}$ is electrolytic cell. The platinum anode is set up around the jet, and the lower part in the cell is filled with $\mathrm{CCl}_{4}$ for preventing the decomposition of falling amalgam after break up of jet, which does not disperse into the electrolytic solution in ultrasonics field owing to the equal acoustic impedance. Before starting the electrolysis, the nozzle is swept with string and the flowing velocity is adjusted as constant. If the time is long for this preparation, a white turbulence is found in the solution, which is considered to be due to the corrosion of unpolarized jet electrode and this phenomenon will be discussed in the following report. The current efficiency is obtained by decomposing the formed amalgam with acid.

The relation between current and the cell voltage with respect to the streaming velocity is expressed in Table 1 in the electrolysis of pure $\mathrm{NaCl}$ solution, in which extremely high cathodic current density is attained, and it decreases with increasing streaming velocity. The accuracy of this current density depends upon the jet length measurements, which will be also precisely investigated in the following paper.

The results of the electrolysis of a pure $\mathrm{NaCl}$ solution with a jet cathode is shown in $\mathrm{Table} 2$, in which the differential current efficiency with respect to the salt decomposition ratio is described.

Table 2 Results of the Electrolysis in Pure $\mathrm{NaCl}$ Solution.

\begin{tabular}{|c|c|c|c|c|}
\hline $\begin{array}{c}\text { Concentration } \\
(\%)\end{array}$ & $\begin{array}{c}\text { Cathodic } \\
\text { current density } \\
\left(\mathrm{A} / \mathrm{dm}^{2}\right)\end{array}$ & $\begin{array}{l}\text { Streaming } \\
\text { velocity } \\
(\mathrm{m} / \mathrm{sec})\end{array}$ & $\begin{array}{c}\text { Salt decomposition } \\
\text { range } \\
(\%)\end{array}$ & $\begin{array}{c}\text { Differential current } \\
\text { Efficiency } \\
(\%)\end{array}$ \\
\hline 30 & 900 & 1 & $\left\{\begin{array}{l}0-4.0 \\
4.0-7.7 \\
7.7-11.7\end{array}\right.$ & $\begin{array}{l}92.7 \\
84.5 \\
82.0\end{array}$ \\
\hline 30 & 900 & 0.5 & $\left\{\begin{array}{l}0-3.0 \\
3.0-6.2 \\
6.2-9.3\end{array}\right.$ & $\begin{array}{l}93.8 \\
86.1 \\
88.8\end{array}$ \\
\hline 15 & 750 & 1 & $\left\{\begin{array}{l}0-4.1 \\
4.1-8.0 \\
8.0-12.2\end{array}\right.$ & $\begin{array}{l}87.0 \\
76.0 \\
74.5\end{array}$ \\
\hline
\end{tabular}

Table 3 Results of the Electrolysis in Impure $\mathrm{NaCl}$ Solution

\begin{tabular}{|c|c|c|c|c|c|c|c|}
\hline \multicolumn{4}{|c|}{ Composition of solution } & \multirow{2}{*}{$\begin{array}{c}\text { Cell voltage } \\
\text { (V) }\end{array}$} & \multirow{2}{*}{$\begin{array}{c}\text { Temperature } \\
\left({ }^{\circ} \mathrm{C}\right)\end{array}$} & \multirow{2}{*}{$\begin{array}{c}\text { Cathodic } \\
\text { current } \\
\text { density } \\
\left(\mathrm{A} / \mathrm{dm}^{2}\right)\end{array}$} & \multirow{2}{*}{$\begin{array}{c}\text { Current } \\
\text { efficiency } \\
(\%)\end{array}$} \\
\hline $\mathrm{NaCl}$ & $\mathrm{FeCl}_{2}$ & $\mathrm{CaCl}_{2}$ & $\mathrm{MgCl}_{2}$ & & & & \\
\hline sat. & - & $0.05 \mathrm{~N}$ & $0.04 \mathrm{~N}$ & $8.5-9.0$ & $17-28$ & 4400 & 96.4 \\
\hline sat. & $1 \times 10^{-4} \mathrm{~N}$ & - & - & $8.5-9.1$ & $14-21$ & 4400 & 96.7 \\
\hline sat. & $1 \times 10^{-4} \mathrm{~N}$ & $0.05 \mathrm{~N}$ & $0.04 \mathrm{~N}$ & $8.6-9.1$ & $16-28$ & 4400 & 94.9 \\
\hline sat. & - & - & $0.8 \mathrm{~N}$ & $8.5-9.0$ & & 4400 & 94.3 \\
\hline $2.6 \mathrm{~N}$ & - & - & $0.6 \mathrm{~N}$ & $6.2-6.4$ & & 2200 & 92.4 \\
\hline
\end{tabular}

Table 4 Results of the Electrolysis in Conc. Saline Water.

\begin{tabular}{|c|c|c|c|c|c|}
\hline $\begin{array}{c}\text { Concentration } \\
(\%)\end{array}$ & $\begin{array}{l}\text { Cathodic } \\
\text { current density } \\
\quad\left(\mathbf{A} / \mathrm{dm}^{2}\right)\end{array}$ & $\begin{array}{c}\text { Streaming } \\
\text { velocity } \\
(\mathrm{m} / \mathrm{sec})\end{array}$ & $\begin{array}{c}\text { Salt decomposition } \\
\text { range } \\
(\%)\end{array}$ & $\begin{array}{l}\text { Differential } \\
\text { current } \\
\text { efficiency } \\
(\%)\end{array}$ & $\begin{array}{c}\mathrm{Mg} / \mathrm{Na} \\
\text { deposit } \\
\text { ratio } \\
(\%)\end{array}$ \\
\hline 20 & 550 & 0.87 & $\left\{\begin{array}{l}0-4.9 \\
4.9-9.3 \\
9.3-13.7\end{array}\right.$ & $\left.\begin{array}{l}83.3 \\
76.7 \\
75.0\end{array}\right\}$ & 0.204 \\
\hline 20 & 850 & 0.60 & $\left\{\begin{array}{l}0-3.6 \\
3.6-7.0 \\
7.0-10.6\end{array}\right.$ & $\left.\begin{array}{l}79.0 \\
72.6 \\
66.4\end{array}\right\}$ & 4.95 \\
\hline 30 & 850 & 0.60 & $\left\{\begin{array}{l}0-3.2 \\
3.2-6.1 \\
6.1-8.0\end{array}\right.$ & $\left.\begin{array}{l}91.7 \\
87.0 \\
76.1\end{array}\right\}$ & 1.14 \\
\hline
\end{tabular}


The high current efficiency is obtained in rather low streaming velocity and during the initial range of salt decomposition ratio. When the solution contains impurities such as $\mathrm{Fe}, \mathrm{Ca}$ and $\mathrm{Mg}$ ions, the results are shown in Table 3 , from which it is suggested that the impure brine water can not be electrolyzed succesfully by the plane mercury method but can be performed by this jet cathode. Then, the electrolysis of concentrated saline water was carried out by the jet cathode, the results of which were shown in Table 4 . The composition of the electrolyte is as follows:

\begin{tabular}{|c|c|c|c|}
\hline Component & $20 \%$ & & $30 \%$ \\
\hline $\mathrm{NaCl}$ & $115 \mathrm{~g}$ & & $233 \mathrm{~g}$ \\
\hline $\mathrm{MgCl}_{2} 4 \mathrm{H}_{2} \mathrm{O}$ & 38 & $1 l$ & 57 \\
\hline $\mathrm{MgSO}_{4} 7 \mathrm{H}_{2} \mathrm{O}$ & 20 & 111 & 30 \\
\hline $\mathrm{K}_{2} \mathrm{SO}_{4}$ & 5 & & 7.5 \\
\hline
\end{tabular}

It is observed in the experiments with the solution containing $\mathrm{Mg}$ ion that the mercury nozzle is sometimes stopped up as the current density is high and the salt decomposition ratio is large. Contrarily when the pure $\mathrm{NaCl}$ solution is electrolyzed with high current density, a beautiful spark discharge is observed at the break up of jet, but the nozzle is not clogged up at all.

The results on the effect of ultrasonics radiation upon the electrolysis in $20 \%$ saline water are shown in Table 5 and 6 . The values of the current efficiency in Table 5 were subjected to statistical

Table 5 The Current Efficiency in Acoustic Field.

\begin{tabular}{c|cccccccccc}
\hline & \multicolumn{10}{c}{ The cathodic current efficiency } \\
\hline No acoustic field & 76.0 & 78.6 & 80.1 & 84.0 & 84.0 & 85.5 & 83.3 & 76.0 & 62.3 & 79.0 \\
Acoustic field & 83.3 & 85.5 & 84.8 & 85.2 & 87.1 & 87.9 & 91.1 & 85.1 & 81.0 & 87.7 \\
\hline
\end{tabular}

Table 6 The Influence of the Intensity of Ultrasonics upon the Electrolytic Efficiency in $20 \%$ Saline Water.

\begin{tabular}{|c|c|c|c|c|c|c|}
\hline & \multicolumn{5}{|c|}{ Ultrasonics intensity (Plate voltage) } & \multirow{2}{*}{$\begin{array}{l}\text { Salt decomposition } \\
\text { Ratio range }(\%)\end{array}$} \\
\hline & none & $500 \mathrm{~V}$ & $750 \mathrm{~V}$ & $850 \mathrm{~V}$ & $1000 \mathrm{~V}$ & \\
\hline Current & 79.0 & 77.0 & 80.6 & 83.0 & 76.4 & $0-3 \%$ \\
\hline Efficiency & 68.6 & 64.6 & 63.2 & 74.7 & 71.3 & $3-6$ \\
\hline$(\%)$ & 67.8 & 56.0 & 64.4 & 73.7 & 68.2 & $6-9$ \\
\hline $\mathrm{Mg} / \mathrm{Na}$ Deposit Ratio (\%) & - & 0.42 & 0.36 & 0.33 & 0.18 & $0-9$ \\
\hline $\begin{array}{l}\text { Streaming Velosity } \\
(\mathrm{m} / \mathrm{sec})\end{array}$ & 1.11 & 1.04 & 1.11 & 1.01 & 1.08 & \\
\hline
\end{tabular}

test, from which it was concluded that the ultrasonics radiation had a significant effect in increasing the current efficiency. The intensity of ultrasonics has the maximum range in its effect on the current efficiency as the same with the previous paper. ${ }^{(2)}$

The limiting current density in the jet electrode has been investigated by several authors and is described as following when the streaming velocity is enough large in presence of the excess of indifferent ions $^{(3)}$ :

$$
i_{1}=4 n F C(D G z)^{1 / 2}
$$

where $C$ represents the bulk concentration of reducible ion, $D$ the diffusion coefficient, $G$ the streaming velocity and $z$ is jet length. In this experiments, the migration current is added to the diffusion current. Therefore, the total current is larger than $i_{1}$ noted above. Further discussions on this mechanism will be reported in the following report. But qualitatively with increasing streaming velocity, the limiting current increases and the high current density is easily obtained in the jet cathode.

The current efficiency depends not only on the current density but also on the salt decomposition 
ratio and amalgam concentration. The current density is determined by the current and the streaming velocity. So the results in Table 2 may be considered as rather a preliminary test of the electrolysis of pure brine and more of its details will be discussed after the actual experiments.

The possibility of performing the electrolysis of impure brine and of even saline water without any purification is most noticable. The impure ion forming films on the cathode in the plane mercury cell decreases the efficiency, but in the jet cathode the surface film is removed as the cathode surface is continuously renewed. Thus the allowance limits of impurities in the electrolyte is far larger than that in the plane mercury cathode.

(Received November 4, 1958)

\section{Literature}

(1) S. Mizuno, S. Toshima, Y. Furukawa, this journal 26, 137 (1958).

(2) S. Mizuno, S. Toshima, ibid. 26, 166 (1958).

(3) A. Rius et al: Anales fis. y. quim. (Madrid) 43, 1074 (1947), 45 501, 1039 (1949), 46, 55, 93 (1950), P. Valenta, Collection 16, 239 (1951). 